\title{
PPOT PROGRAM PEMBINAAN ORANG TUA DI SEKOLAH AL FALAH JAKARTA
}

\author{
Oleh \\ Parina $^{1}$, Budi Handrianto ${ }^{2}$, Anung Al-Hamat ${ }^{3}$ \\ email: sukses45@gmail.com \\ 1,2,3 Sekolah Pascasarjana MPAI UIKA Bogor, Indonesia
}

\begin{abstract}
The purpose of this study was to obtain an overview of the parental coaching program carried out at Al Falah School in Jakarta to find out the background, goals, obstacles and benefits of the parental development program at Al Falah School which is called the Program Pelatihan Guru dan Orang Tua (PPOT). The method used in this research is a case study. Cooperation between the school and parents of students is very important to achieve educational goals. The synergy of education at home and school is needed so that educational programs in schools can be continued at home or vice versa. Family education is the basis and key to further education. So that the center of education should be at home. But today the center of education is moving from home to school. Parents are not ready to become educators for their children. Al-Falah School requires parents to be involved in their children's education, not only fully surrendering education to the school. Parents must be able to be good teachers for their children because parents are the first teachers, schools help parents as second teachers. In order to increase the capacity of parents, schools require parents to take part in a training program called Program Pelatihan Guru dan Orang Tua (PPOT). PPOT in Al Falah is carried out using various methods so that it can make parents aware of being educators for their children and also make parents have skills in educating their children.
\end{abstract}

Keywords: Sinergy, Parent, School.

\begin{abstract}
ABSTRAK
Tujuan penelitian ini untuk mendapatkan gambaran program pembinaan orang tua yang dilakukan di Sekolah Al Falah Jakarta, mengetahui latar belakang, tujuan, hambatan dan manfaat program pembinaan orang tua di Sekolah Al Falah yang disebut dengan Program Pelatihan Guru dan Orang Tua (PPOT). Metode yang yang digunakan dalam penelitian ini adalah studi kasus. Kerjasama antara sekolah dan orang tua siswa sangat penting untuk tercapainya tujuan pendidikan. Sinergitas pendidikan di rumah dan sekolah sangat dibutuhkan agar program pendidikan disekolah dapat diteruskan di rumah atau sebaliknya. Pendidikan keluarga merupakan dasar dan kunci pendidikan selanjutnya. Sehingga sentral pendidikan seharusnya ada di rumah. Namun hari ini sentral pendidikan berpindah dari rumah ke sekolah. Orang tua tidak siap menjadi pendidik untuk anak - anaknya. Sekolah Al - Falah mewajibkan orang tua untuk terlibat dalam pendidikan anaknya tidak hanya menyerahkan sepenuhnya pendidikan kepada sekolah. Orang tua harus mampu menjadi guru yang baik untuk anak - anaknya karena orang tua adalah guru pertama, sekolah membantu orang tua sebagai guru ke dua. Dalam rangka meningkatkan kapasitas orang tua, sekolah mewajibkan kepada orang tua untuk mengikuti program pembinaan yang disebut dengan Program Pelatihan Guru dan orang Tua (PPOT). PPOT di Al Falah dilakukan dengan berbagai macam metode sehingga mampu menyadarkan orang tua sebagai pendidik bagi anak-anaknya dan juga membuat orang tua memiliki skill dalam mendidik anak - anaknya.
\end{abstract}

Kata kunci : Sinergi, Orang Tua, Sekolah. 


\section{A. PENDAHULUAN}

Pendidikan seorang anak menjadi tanggungjawab bersama antara orang tua, sekolah dan juga masyarakat. Orang tua sebagai pendidik (guru) pertama dan utama bagi anak - anaknya bertanggungjawang memberikan pendidikan awal yang berkualitas dan terus menemani mereka berkembang dalam waktu yang tidak terbatas. Program pengasuhan dirancang oleh orang tua dalam rangka menanamkan berbagai macam aturan hidup dalam diri anak dengan bimbingan dan arahan penuh kasih sayang kepada anak-anaknya di rumah.

Sekolah sebagai guru kedua berfungsi membantu orang tua dalam mendidik dan menemani anak - anak mereka tumbuh berkembang pada masa waktu tertentu. Sekolah dibuat untuk membantu orang tua karena keterbatasan yang dimilikinya. Keterbatasan pengetahuan dalam hal mendidik anak maupun keterbatasan waktu yang dimiliki oleh orang tua karena berbagai kesibukannya. Namun, kewajiban orang tua dan tanggungjawab mereka dalam mendidik anak - anaknya tidak hilang begitu saja walaupun telah menitipkannya kepada sekolah. Pada saat ini peran orang tua sebagai sentral dalam hal mendidik anak mulai berkurang. Hal ini terlihat dibanyak kasus orang tua yang mengabaiakan peran ini dan menyerahkannya kepada sekolah. Bukti lain lemahnya orang tua dalam memahami tumbuh kembang anaknya serta pengetahuan dalam mendidiknya akan menyebabkan pola asuh dirumah tidak sejalan dengan program dan pendidikan di sekolah.(Hardianto, 2014) Oleh karena itu perlu dilakukan program atau kegiatan pembinaan orang tua agar terjadi sinergisitas dalam pendidikan anak antara orang tua dan sekolah sehingga tujuan pendidikan yang diinginkan bersama dapat dicapai.

Sekolah pada umumnya telah berusaha membuat program pembinaan atau kegiatan dalam rangka terbangunnya sinergisitas atau kerjasama antara sekolah dan orang tua. Namun dalam prakteknya ditemukan beberapa kendala karena program pembinaan kepada orang tua biasanya dilakukan secara rutinitas dan bersifat umum serta tidak mengikat. Mulai terkendala dengan kesiapan waktu kedua orang tua sehingga sering dijumpai bahwa sebagian besar dihadiri oleh salah satu dari dua orang tua siswa, biasanya di dominasi oleh para ibu. Materi yang diberikan bersifat umum dan informasi konsep serta program sekolah 
disampaikan secara sekilas. Proses pembinaan orang tua tidak dijadikan satu bagian sistem yang tidak terpisahkan dari proses pendidikan di sekolah tersebut.

Pemerintah dalam hal ini Menteri Pendidikan dan Kebudayaan menerbitkan regulasi terkait dengan pelibatan keluarga dalam penyelenggaraan pendidikan. Hal semakin menegaskan strategisnya peran keluarga atau orang tua dalam proses pendidikan. Pada tahun 2017 Kemetrian Pendidikan dan Kebudayaan (Kemendikbud) menerbitkan Peraturan Menteri Pendidikan Dan Kebudayaan Republik Indonesia Nomor 30 Tahun 2017 Tentang Pelibatan Keluarga Pada Penyelenggaraan Pendidikan. Tujuan pelibatan keluarga pada penyelenggaraan pendidikan yaitu agar terjadinya peningkatan kepedulian dan tanggung jawab bersama, menguatkan pendidikan karakter, serta adanya sinergitas antara sekolah, orang tua, dan masyarakat sehingga terwujudnya suasana yang aman dan nyaman serta menyenangkan di lingkungan satuan pendidikan tersebut.

Sekolah Al Falah, salah satu sekolah di Jakarta yang berdiri sejak tahun 1996 dengan salah satu pendirinya Wismiarti Tamim, memiliki program pembinaan orang tua yang dikenal dengan nama Program Pelatihan Guru dan Orang
Tua (PPOT) yang telah dimulai sejak tahun 2004. Ada tujuh PPOT yang disiapkan oleh Sekolah Al Falah untuk para guru dan orang tua murid. Semua PPOT ini dilakukan secara berurutan. Dalam kegiatan ini orang tua bukan hanya mendapatkan materi pemahaman namun juga menjalani observasi dan praktik. Tujuannnya agar orang tua mengetahui program sekolah dan melanjutkan dirumah. Sebelumnya Wismiarti mencoba berbagai cara parenting tetapi tidak berhasil menarik perhatian orang tua. Padahal, program ini gratis dan pesertanya dijamu. Namun setelah dimasukkan dalam program sekolah dan orang tua wajib mengikutinya maka program ini dapat berjalan dengan baik walaupun ada pembayarannya.(Kasali, 2019)

Pembinaan orang tua yang dikelola secara serius dan tersistem akan membantu tugas sekolah dalam melakukan proses pendidikannya. Proses pendidikan akan berjalan sesuai yang diharapkan karena orang tua memiliki kesamaan konsep serta pengetahuan dasar dalam menemani anak - anaknya tumbuh dan berkembang dirumah. Pola pendidikan disekolah akan diteruskan dirumah sehingga tercipta sinergisitas 
antara sekolah dan rumah dalam melaksanakan program pendidikan.

Penelitian ini mempunyai tujuan untuk menyadarkan semua pihak akan pentingnya pendidikan yang sinergi antara sekolah dan rumah. Selain itu juga menginformasikan kepada sekolah sekolah bahwa dengan melakukan pembinaan kepada orang tua secara sistemik dan serius akan sangat membantu sekolah dalam menjalankan program pendidikannya.

Rumusan masalah dalam penelitian ini adalah bagaimanakah program pembinaan orang tua siswa di Sekolah Al Falah Jakarta?

\section{B. METODE PENELITIAN}

Penelitian ini adalah penelitian kualitatif dengan jenis studi kasus. Menurut Bogdan dan Taylor, sebagaimana yang dikutip oleh Lexy J. Moleong, penelitian kualitatif adalah prosedur penelitian yang menghasilkan data deskriptif berupa kata-kata tertulis atau lisan dari orang-orang dan perilaku yang diamati. (Moleong, 2000) Penelitian yang dilakukan dalam waktu tertentu serta mendalam dalam meneliti tentang suatu organisasi, satu program tertentu atau tentang kelompok atau individu disebut penelitian studi kasus. Tujuan penelitian ini untuk mendapatkan gambaran yang menyeluruh dan mendalam dari sebuah kelompok. Sebagaimana penelitian kualitatif lainnya, prosedur perolehan data diperoleh melalui wawancara, observasi, dan arsip.(Raharjo, 2019) Penelitian ini dilakukan pada bulan Mei 2020 sampai dengan Agustus 2020 di Sekolah Al Falah Jakarta.

Pengumpulan data dilakukan melalui wawancara kualitatif, pengamatan, wawancara dan analisis dokumen. Peneliti mewawancarai Direktur Pendidikan Sekolah Al Falah, dan pihak-pihak lain yang dapat memberikan informasi terkait fokus penelitian. Teknik analisi data yang digunakan merujuk kepada analisis data Miles \& Huberman. Adapun analisis data kualitatif terdiri dari alur kegiatan yaitu pengumpulan data, reduksi data, penyajian data dan penarikan kesimpulan/verifikasi. (Miles \& Huberman, 1992) Adapun skema itu digambarkan sebagai berikut:

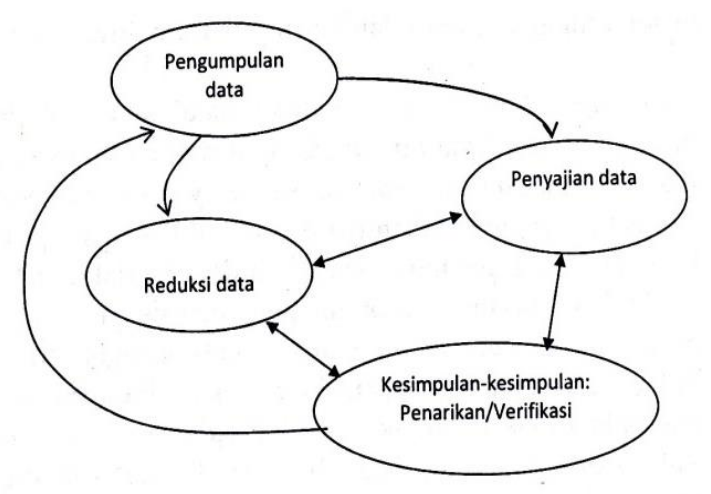

Gambar 1. Gambar Skema Analisis Data 
Reduksi data diartikan sebagai proses pemilihan, pemusatan perhatian pada penyederhanaan, pengabstrakan, dan transformasi data 'kasar' yang muncul dari catatan-catatan tertulis di lapangan. Dari sekian banyak data yang terumpul, maka peneliti dapat memusatkan perhatian dengan membuat kategori.

Penyajian data sebagai sekumpulan informasi tersusun yang memberi kemungkinan adanya penarikan kesimpulan dan pengambilan tindakan. Dari tahapan reduksi dengan didapatkannya kategori dari catatan lapangan yang terkumpul, maka pada tahap penyajian data sudah dapat ditarik kesimpulan.

\section{HASIL DAN PEMBAHASAN}

\section{Pendidikan dalam Perspektif Islam}

Pendidikan berasal dari bahasa Yunani dari kata "paedagogie" yang terdiri dari dua kata yaitu "pais" artinya anak dan "again” berarti membimbing, jadi paedagogie artinya memberikan bimbingan kepada anak. Sedangkan dalam bahasa Inggris pendidikan diistilahkan dengan kata "to educate" yang berarti melatih intelektual serta memperbaiki moral.(Sholichah, 2018)

Dalam Kamus besar bahasa Indonesia disebutkan Pendidikan adalah proses pengubahan sikap dan tata laku seseorang atau kelompok orang dalam usaha mendewasakan manusia melalui upaya pengajaran dan pelatihan, proses, cara, perbuatan mendidik.

Pendidikan merupakan usaha sistematis yang bertujuan agar setiap manusia mencapai satu tahapan tertentu di dalam kehidupannya, yaitu tercapainya kebahagian lahir dan batin.(Yusuf, 2018)

Pendidikan adalah suatu proses pengembangan diri dan kehidupan manusia secara utuh dan menyeluruh di berbagai bidang kehidupan sesuai dengan keberadaan manusia.(Ilyasir, 2017)

Menurut undang - undang No. 20 tahun 2003 tentang sistem pendidikan nasional, pendidikan merupakan usaha yang dilakukan secara sadar dan terencana untuk mewujudkan proses belajar dan suasana pembelajaran yang memungkinkan peserta didik aktif mengembangkan potensi yang dimilikinya sehingga akan menjadi pribadi memiliki kekuatan spiritual keagamaan, pengendalian diri, kepribadian, kecerdasan, akhlaq mulia, serta keterampilan yang diperlukan dirinya, masyarakat bangsa dan Negara.

Menurut Ahmad Tafsir pendidikan memiliki arti yang sangat luas karena bukan hanya kegiatan yang sadar saja yang masuk dalam kategori pendidikan 
namun kegiatan yang yang tidak sadarpun termasuk pendidikan seperti pendidikan oleh lingkungan, kebudayaan, alam dan sebagainya. Selain itu, pendidikan bukan hanya kegiatan yang dilakukan oleh orang lain saja, namun kegiatan yang kita lakukan terhadap diri sendiri pun juga termasuk pendidikan.(Tafsir, 2016)

Berdasarkan definisi diatas bahwa pendidikan merupakan semua aktivitas pengalaman hidup dalam rangka mengembangkan potensi manusia secara utuh dan menyeluruh agar dapat menyelesaikan tugas kehidupannya kelak sehingga tidak terbatas hanya tranfer informasi yang bersifat kognitif semata namun mencakup semua potensi sebagai manusia agar mencapai kebahagiaan dunia dan akhirat.

Dalam Islam, kata pendidikan salah satu maknanya adalah tarbiyah. Istilah ini tidak ditemukan didalam Al-Qur'an, asSunah maupun dalam buku - buku para ulama klasik. Yang ada pada masa itu adalah kata - kata yang mengandung makna tersebut. Kata Tarbiyah atau lengkapnya dengan Tarbiyah Islamiyah merupakan istilah baru dalam dunia pendidikan yang muncul pada masa kini.(Al-Hamat, 2016)

Menurut Abudin Nata, setidaknya ada 13 kosakata yang digunakan oleh para tokoh pendidikan Islam untuk menjelaskan pengertian pendidikan dan pengajaran, diantaranya al-tarbiyah, alta'lim, al-ta'dib,al-tahzib, al-tazkiyah, al$w a ' d z$ atau almau'idah,Al-riyadhah, altalqin, al-tadris,al-tafaqquh, al-tabyin, altazkirah dan al-irsyad '. Hal ini menunjukkan keseriusan Islam dalam pendidikan serta memberikan gambaran betapa luasnya cakupan kegiatan pendidikan dalam pembinaan manusia seutuhnya. Sehingga pengertian pendidikan Islam mengandung arti kegiatan dalam bentuk arahan, bimbingan, pembinaan, perintah, peringatan, pemberian pengetahuan, penjelasan, pendalaman, pemahaman, pencerahan akal dan spiritual, pencerdasan, pengajaran dan penyucian diri.(Nata, 2017)

Pendidikan Islam menurut Syed Naquib al-Attas, seperti dikutip oleh Maturidi dalam bahwa "pendidikan Islam merupakan proses transinternalisasi nilainilai Islam kepada peserta didik sebagai bekal mencapai kebahagiaan dan kesejahteraan di dunia dan di akhirat".(Maturidi, 2016)

Menurut Abudin Nata, pendidikan yang seluruh komponen atau aspek pendidikannya mendasarkan kepada ajaran Islam disebut pendidikan 
Islami.(Nata, 2017) Penyusunan visi, misi dan tujuan pendidikan disekolah, proses kegiatan belajar dan mengajar, pendidik dan peserta didik serta hubungan keduanya, kurikulum serta bahan ajar, manajemen sarana prasarana, pengelolaan pendidikan, lingkungan dan aspek atau komponen pendidikan lainnya berdasarkan kepada ajaran Islam.

Menurut Anung Al-Hamat pendidikan Islami adalah "pendidikan yang berorientasi kepada lima pilar agama (keimanan, adab, akhlak, ibadah, dan muamalat). Sehingga melahirkan manusia - manusia yang kuat imannya, benar ibadahnya, baik akhlak dan adabnya serta mampu berinteraksi dengan masyarakat dan bisa terlibat dalam kehidupan sesuai dengan keahlian yang dimilikinya".(AlHamat, 2016)

Pendidikan Islam adalah usaha yang dilakukan pendidik untuk mengembangkan seluruh potensi yang miliki oleh manusia agar mampu mencapai kesempurnaan penciptaannya sehingga manusia tersebut dapat memainkan perannya sebagai makhluk tuhan yang beriman, berilmu dan berakhlakul karimah.(Hidayat, 2016)

Dari beberapa pengertian pendidikan Islam diatas dapat disimpulkan bahwa pendidikan Islam memiliki pengertian yang sangat luas yang mencakup semua kegiatan atau usaha yang berdasarkan ajaran Islam untuk mengembangkan seluruh potensi manusia agar menjadi manusia yang seutuhnya agar mampu mengemban tugas kehidupannya.

\section{Peran Orang Tua sebagai Pendidik di Rumah}

Rumah keluarga muslim adalah benteng utama tempat anak - anak dibesarkan melalui pendidikan Islam. Dan keluarga muslim yang dimaksud adalah keluarga yang menjadikan dasar aktivitas pembentukan keluarganya kepada syariat Islam. Dalam konsepsi Islam keluarga atau orang tua sebagai penanggungjawab utama terpeliharanya fitrah anak.(AlNahlawi, 1996)

Keluarga adalah wadah pertama dan utama pertumbuhan dan pengembangan anak. Jika suasana dalam keluarga itu baik dan menyenangkan maka anak akan tumbuh dengan baik. Namun sebaliknya tumbuh kembang anak dapat terganggu jika suasana di keluarga terjadi hal yang sebaliknya.(Daradjat, 1994)

Menurut Muhammad Qutub sebagaimana dikutip oleh Ahmad Asysyantut, rumah merupakan sarana terpenting dan utama dalam mempengaruhi anak - anak diawal 
pertumbuhannya karena di rumahlah anak menghabiskan waktu Bersama orang tua, dibandingkan dengan waktu - waktu lain di luar rumah dan karena orang tualah yang paling berpengaruh kepada kepribadian anak. Dan Alloh membebankan kepada orang tua untuk bertanggungjawab dalam menjaga fitrah dalam diri anak, bahkan orang tua menjadi penentu tumbuh kembangnya fitrah dalam diri anak.(asy-Syantut, 2005)

Menurut Ahmad Tafsir orang tua menjadi penanggungjawab pertama dan utama dalam pendidikan anak. Yang bertindak menjadi pendidik adalah ayah dan ibu serta semua orang merasa bertanggungjawab terhadap perkembangan anak seperti kakek, nenek, paman, bibi dan kakak, namun yang paling bertanggungjawab adalah ayah dan ibu. Dan pendidikan keluarga ini bertanggungjawab terhadap seluruh aspek perkembangan anak, yaitu jasmani, akal dan ruhani.(Tafsir, 2016)

Selain itu keluarga merupakan sumber pertama kebenaran atau pengetahuan, sehingga pondasi pendidikan anak adalah keluarga atau rumah tangga. Penananam dan penumbuhan sebuah nilai kepada seorang anak dapat berlangsung sejak kelahirannya bahkan dalam kandungan.
Oleh karena itu keluarga sangat berperan dalam mengembangkan potensi fitrah anak. Seorang anak yang lahir dalam keluarga muslim memiliki modal utama dan juga lingkungan yang sangat kondusif untuk nilai ilahiah dapat tumbuh dan berkembangnya dengan baik dalam dirinya. Namun demikian, nilai ilahiah ini masih bersifat tradisional yang belum terkoreksi sepenuhnya oleh pengetahuan agama dari lembaga pendidikan di luar rumah yang diterimanya. Hal ini terjadi karena pada umumnya suatu nilai tersosialisasikan secara turun temurun. Corak nilai ilahiah yang tumbuh itu sejalan dengan nilai-nilai agama yang berkembang di lingkungan keluarga yang sangat mungkin belum sesuai semua dengan ajaran Islam.(Buseri, 2014)

Menurut khalid Ahmad Syantut, Islam sangat peduli dengan kualitas keluarga karena keluarga merupakan fondasi pendidikan lekat kepada anak anak, khususnya fase usia dini. Sebab masa kanak - kanak merupakan masa yang panjang, dimasa itu karakter anak anak masih sangat jernih dan lembut. Kita bisa menanamkan apa saja yang kita mau. Jika pada fase ini kita berikan asuhan dan bimbingan yang tepat maka mereka akan menjadi kuat dan kokoh untuk meghadapi cobaan saat dewasa.(Syantut, 2019) 
3. Peran Sekolah dalam Pendidikan Anak

Sekolah merupakan suatu satuan pendidikan pada jalur pendidikan formal. Dalam UU No. 20 Tahun 2003 pasal 1 disebutkan bahwa satuan pendidikan merupakan kelompok layanan pendidikan yang menyelenggarakan pendidikan pada setiap jenis dan jenjang pendidikan baik formal, non formal maupun infiormal. Dalam kajian ini yang dimaksudkan dengan sekolah merupakan kelompok layanan pendidikan yang menyelenggarakan pendidikan pada jalur pendidikan formal.

Fungsi utama sekolah dalam konsep Islam adalah mewujudkan pendidikan berlandaskan tujuan pemikiran, akidah dan aturan agama sehingga mampu melahirkan penghambaan diri kepada Alloh serta mengesakan-Nya. Selain itu juga untuk mengembangkan potensi dan bakat manusia sesuai fitrahnya agar terhindar dari penyimpangan. Selain fungsi utama ini, sekolah juga memiliki fungsi fundamental lainnya, diantaranya : fungsi penyederhanaan dan penyimpulan, fungsi penyucian dan pembersihan, fungsi mempeluas wawasan dan pengalaman anak, fungsi mewujudkan keterikatan, integritas, hegemonitas dan keharmonisan antarsiswa, fungsi penyempurna tugas keluarga dalam pendidikan. Sehingga sekolah bukanlah sentral pendidikan karena pendidikan awal anak berpusat di rumah.(Al-Nahlawi, 1996)

\section{Sinergisitias Pendidikan Sekolah Dan Rumah}

Menurut Hampden-Turner seperti dikutip oleh Siti Sulasmi, sinergi berasal kata Yunani, yaitu syn-ergo yang berarti bekerjasama. Walton membuat definisi yang paling sederhana yaitu hasil upaya kerjasama atau 'co-operative effort', sehingga kerjasama merupakan inti dari proses untuk dihasilkannya kualitas sinergi.(Sulasmi, 2018)

Sulasmi dalam pidato pengukuhannya jabatan guru besar dalam bidang ilmu manajemen pada fakultas ekonomi dan bisnis Universitas Airlangga di Surabaya mendefinisikan sinergi sebagai hasil dari suatu proses perpaduan dari cara-cara bagaimana mengatasi masalah dan perpaduan gagasan yang dijalankan oleh pihak-pihak yang saling percaya dan bersikap saling mendukung.(Sulasmi, n.d.)

Menurut Pendidikan Islam, konsep pendidikan keluarga adalah pendidikan awal yang dilakukan oleh orang tua terhadap anak atas dorongan kasih sayang yang merupakan kewajiban yang akan dipertanggungjawabkan kepada Alloh 
kelak. Pendidikan di sekolah menurut konsep pendidikan Islam adalah lembaga formal yang secara efektif melaksanakan proses pendidikan yang mengantarkan anak pada tujuan pendidikan Islam. Bertolak dari konsep tersebut maka pendidikan sekolah tidak bisa berupaya bersama gurunya tanpa kerjasama dari orang tua atau keluarga. Sekolah berfungsi membantu keluarga dalam proses pendidikan dan pengajaran kepada anak didik, pendidikan di sekolah merupakan keberlanjutan dari pendidikan yang telah diberikan di rumah atau keluarga.(Amin, 2018)

Kemitraan dan pemberdayaan orang tua dapat dibangun oleh sekolah dengan memberikan workshop, tutorial atau tugas monitoring kepada orang tua yang disesuaikan dengan kebutuhan mereka dengan tujuan untuk lebih memahami perkembangan anaknya dan sekaligus sebagai bentuk kepedulian sekolah dalam mewujudkan keberhasilan anak - anak mereka.(Fatchurrohman, 2012)

Berdasarkan Permendikbud Nomor 30 tahun 2017 tentang Pelibatan Keluarga Pada Penyelenggaraan Pendidikan, disebutkan bentuk pelibatan keluarga dalam membangun kemitraan dengan sekolah, diantaranya menghadiri pertemuan yang diselenggarakan oleh sekolah, sebagai peserta kelas orang tua/wali, menjadi narasumber dalam kegiatan yang diselenggarakan sekolah, berperan aktif dalam kegiatan pentas kelas akhir tahun pembelajaran, terlibat dalam kegiatan pengembangan diri anak seperti kegiatan kokurikuler, ekstra kurikuler, tidak menolak menjadi anggota komite sekolah serta aktif dalam kegiatannya, menjadi anggota tim pencegahan kekerasan di sekolah, berperan aktif dalam kegiatan pencegahan pornografi, $\quad$ pornoaksi, dan penyalahgunaan narkoba, psikotropika, dan zat adiktif lainnya (NAPZA) serta dapat meemfasilitasi atau berperan aktif disekolah dalam kegiatan penguatan pendidikan karakter anak.

\section{Profil Sekolah Dasar Al Falah.}

Sekolah Al-Falah Jakarta saat ini memiliki sekolah semua tingkatan sekolah mulai dari prasekolah, sekolah dasar hingga sekolah menengah, baik menengah pertama maupun atas. Pada awalnya sekolah ini menempati lahan seluas 12 ribu meter persegi di daerah Kelapa Dua Wetan, Ciracas, Jakarta Timur. Sejak tahun ajaran 2015 Sekolah Al Falah resmi pindah ke lokasi baru di Cipayung, Jakarta Timur atau sekitar $2 \mathrm{~km}$ jaraknya dari lokasi sebelumnya dengan luas lahan sekitar 14 ribu meter persegi. Sekolah 
Dasar Al Falah berada di komplek Sekolah Al Falah dengan alamat : Jl. Malaka No. 1D, Rt. 005/Rw.04. Muncul, Cipayung, Jakarta Timur.

Sekolah Al Falah didirikan oleh salah satunya pendirinya adalah Wismiarti. Menurut Rhenald Kasali, Wismiarti merupakan sosok yang unik yang memiliki latar belakang dokter gigi, seorang PNS di Pemprov DKI yang melepaskan jabatan prestisiusnya sebagai Direktur Lembaga Pengawasan Doping DKI pada tahun 1996 - 1998, kemudian hijrah dari dunia kesehatan ke dunia pendidikan karena keprihatinan yang terjadi di dunia pendidikan. Keprihatinan ini terjadi saat mempersiapkan sebuah laboratorium doping sebagai bagian dari persiapan Jakarta menjadi tuan rumah PON XIV pada 1996 dan Sea Games XIX pada tahun 1997 dengan melakukan seleksi untuk mencari anggota tim senior di laboratorium tersebut. Sebanyak lebih dari 200 orang dengan latar pendidikan tinggi hingga S-3 bidang farmasi dan biokimia namun yang dinyatakan lolos seleksi oleh tim seleksi hanya dua (2) orang. Tim seleksi di ketua oleh Dr. Rymantas Kazlauskas, Direktur Australian Sports Drug Testing Laboratory. Penyebab tidak lolosnya peserta karena salah satunya adalah terkait konsistensi. Hal ini menimbulkan sebuah pertanyaan kenapa orang yang pandai berfikirnya tinggi tidak konsisten? Setelah bertanya dan mencari jawaban dari para pakar di Indonesia maupun di luar negeri akhirnya menemukan jawabannya. Para pakar menjelaskan, hal ini disebabkan oleh kurang tepatnya pendidikan yang mereka dapatkan dari keluarga atau lingkungannya pada saat usia dini. Sejak saat itu mulailah Wismiarti mencari literatur - literatur tentang pendidikan usia dini dan ketika melakukan perjalanan ke luar negeri baik dinas maupun pribadi, selalu melihat penyelenggaraan pendidikan usia dini di negara tersebut. Dan baru menyadari apa perbedaan antara pendidikan usia dini di Indonesia dan di luar negeri. Berdasarkan hal - hal tersebut maka Wismiarti memutuskan untuk terjun ke dunia pendidikan.(Kasali, 2019)

Pada bulan Maret tahun 1996, Wismiarti mendirikan yayasan yang menaungi Sekolah Al-Falah bersama Wakil Gubernur DKI Jakarta R. S. Museno dan Kepala Kanwil Pendidikan DKI Jakarta Kusnan Ismukanto. Penerimaan siswa baru untuk level TK atau Prasekolah direncanakan akan dimulai pada bulan Juni 1996. Wismiarti adalah orang pertama kali 
memperkenalkan dan mengembangkan BCCT (Beyond Center Circle Time) di Indonesia. BCCT ini kemudian familier dikenal dengan nama Sentra. Dalam rangka membangun sekolah berbasis sentra Wismiarti mengirimkan guru tiga orang gurunya untuk belajar langsung ke Florida, tempat Dr. Pamela Phelp mengembangkan BCCT di Amerika dengan biaya dari uang pribadi sendiri.(Kasali, 2019)

Perjalanan Sekolah Al Falah pada fase awal lumayan lancar, segala macam perizinan tidak menemui kendala berarti. Walaupun aset - asset pribadi terpaksa dijual untuk mencukupi biaya operasional sekolah, diantaranya beberapa unit mobil, dua klinik spesialis gigi serta aset lainnya. Hal ini beliau lakukan untuk membangun pendidikan yang berkualitas bukan hanya sekedar memiliki sekolah, namun krisis moneter yang menerjang Indonesia dan negara kawasan Asia yang mengakibatkan kenaikan suku bunga yang tidak terkendali ikut mempengaruhi perjalanan Sekolah Al Falah. Kepemilikan tanah dan bangunan yang baru awal beroperasi harus berpindah tangan. Namun pemilik yang baru mengizinkan Sekolah Al Falah untuk menggunakan bangunan yang ada untuk beberapa waktu. Pada tahun 2004, Sekolah Al - Falah membeli tanah seluas
14 ribu meter persegi di kawasan Cipayung yang saat ini ditempati dengan bantuan pembiayaan bank Syariah, penjualan aset pribadi serta pinjaman dari seorang notaris.(Kasali, 2019)

Penerimaan siswa TK dimulai pada tahun 1996 dengan menerima siswa 4 orang yang terdiri dari tiga anak guru dan satu anak pengurus yayasan. Guru Al Falah yang berjumlah enam guru dan staf dari Creative Preschool selama satu tahun menyusun kurikulum dan praktek langsung menjalankan metode sentra dengan empat murid. Sekolah Al Falah belum membuka kelas umum. Alasannya pendidikan harus dijalankan sesuai dengan kebutuhan dan tahap perkembangan anak untuk pendidikan anak usia dini. Sehingga sentra yang dijalankan di Creative Preschool tidak bisa langsung diterapkan begitu saja kepada anak - anak Indonesia. Karena itu kemampuan guru untuk membaca tahap perkembangan dan memberikan dukungan pembelajaran yang sesuai merupakan hal yang pertama kali harus dibangun.(Kasali, 2019)

Pada tahun 1997, Sekolah Al Falah menerima murid baru yang jumlahnya tidak melebihi murid yang sudah ada. Hal ini dilakukan untuk menjaga kekuatan peer group. Dan pada tahun yang sama 
mulai menerima siswa tingkat SD dari kalangan internal guru. Pada tahun 1998, setelah 20 orang gurunya mempunyai kemampuan untuk menyusun kurikulum/Lesson Plan sendiri sesuai kebutuhan anak maka Sekolah Al Falah membuka kelas umum. Pada tahun 2002 mulai menerima siswa SMP dan tahun 2005 menerima siswa SMA. Dan murid muridnya berasal dari Sekolah Al Falah juga. Saat ini jumlah siswa SD Al Falah berjumlah 71 dengan jumlah guru 10 orang untuk guru SD dan 63 orang untuk jumlah guru secara keseluruhan.(Ridwan, personal communication, 2020)

\section{Program Pembinaan Orang Tua SD} Al Falah.

Program pembinaan orang tua di Sekolah Al Falah yang dilaksanakan dalam bentuk pelatihan disebut Program Pelatihan Guru dan Orang Tua yang disingkat menjadi PPOT. Latar belakang diselenggarakan program PPOT ini merupakan bagian dari syarat untuk mendirikan sekolah, kondisi orang tua di Sekolah Al Falah serta pemahaman di Al Qur'an bahwa anak itu di serahkan Alloh kepada kedua orang tuanya bukan kepada orang lain. Hal ini seperti yang diungkapkan oleh Wismiarti, "Persyaratan (mendirikan) sekolah, ditambah kenyataan yang ada dikita, memang banyak orang tua yang tidak paham pendidikan anak dan ditambah juga pemahaman di Al qur'an bahwa anak itu sebetulnya di serahkan Alloh kepada kedua orang tuanya, tapi orang tua menyerahkan ke orang lain yang disebut guru itu".(Wismiarti, personal communication, 2020) Hal ini juga merupakan pengertian yang dipahami dan yang disampaikan juga oleh konsultan Sekolah Al Falah bahwa secanggih apapun sekolah, tidak ada sekolah yang mampu mendidik anak tanpa kerjasama dengan orang tua. Sehingga yang mendidik anak itu tidak hanya sekolah, karena menurut Wismiarti, guru anak itu ada tiga, orang tua, guru disekolah dan lingkungan. Ketiganya harus terlibat, guru yang utama adalah orang tua, orang tua yang memilih sekolah untuk anaknya yang seharusnya sesuai tujuan orang tua. Aktivitas anak juga banyak bersama orang tua serta orang tualah yang lebih mengetahui dan memahami lingkungan didalam maupun diluar rumahnya, sehingga idealnya rencana belajar anak itu disusun bersama orang tua. Di negara negara maju pendidikan orang tuanya sudah tinggi sehingga saat diajak kerjasama oleh sekolah mereka langsung mengerti. Sekolah Al Falah membuat program pendidikan orang tua agar guru 
utama yaitu orang tua dapat bekerja bersama dengan guru dalam melaksanakan program pendidikan anak.

Tujuan penyelenggaraan kegiatan ini untuk menyiapkan tim guru anak, ketiga guru anak harus bekerja dalam tim untuk melaksanakan program pendidikan. Melalui kegiatan PPOT ini orang tua diharapkan mengetahui program sekolah dan melanjutkannya dirumah. Sehingga tujuan PPOT ini agar orang tua dapat menjadi guru untuk anak - anaknya saat di rumah, dengan harapan program pendidikan dan pembelajaran di sekolah dapat terus berjalan dengan baik di rumah. Hal ini sangat penting agar antara sekolah dan rumah saling sinergi dalam memberikan pendidikan sehingga hal hal baik yang telah dibentuk disekolah semakin dikuatkan di rumah. Hal ini seperti yang diungkap Wismiarti, salah satu pendiri Sekolah Al Falah :

"Semua anak yang ingin bersekolah di sini kita terima. Tapi yang kami pilih adalah orang tuanya. Kami mencari orang tua yang mau bekerja sama dengan sekolah untuk mengurus anak mereka. Program kami tidak akan berhasil tanpa peran orang tua. Kami selalu sampaikan pada setiap orang tua yang masuk ke sini, secanggih apapun sekolah itu, tidak ada sekolah yang sanggup mendidik anak sendirian tanpa kerjasama dengan orang tua".("Sekolah Al Falah: Orang Tua Wajib Terlibat," 2015)

Orang tua wajib mengikuti kegiatan PPOT 1 sampai PPOT 6 tanpa terkecuali. Sejak awal mendaftarkan anaknya ke Sekolah Al Falah, orang tua murid dijelaskan berbagai komitmen yang salah satunya adalah mengikuti kegiatan PPOT. Saat ini di Sekolah Al Falah cukup banyak siswa yang merupakan anak atau cucu dari pejabat tinggi negara. Semua tanpa terkecuali harus mengikuti program PPOT ini.(Kasali, 2019) PPOT 1 diikuti orang tua sebelum anaknya masuk sekolah, dan PPOT 2 sampai enam dilanjutkan setelah anaknya bersekolah di Al Falah.

Pada kondisi pandemik ini orang tua merasakan manfaat PPOT yang selama ini diikutinya. Orang tua yang telah melaksanakan PPOT 1 sampai PPOT 6 dapat melaksanakan program pendidikan anak di rumah dengan baik dan orang tua yang baru menyelesaikan PPOT 1 atau 2 mengalami kesulitan. Hal ini seperti yang diungkapkan Wismiarti, "Di saat pandemik ini orang tua yang sudah ikut PPOT 1 sampai PPOT 6 lancar kasih program kepada anaknya di rumah dan yang baru ikut PPOT 2 terbata - bata 
karena belum mendapatkan materi tahap perkembangan anak".(Wismiarti, personal communication, 2020)

Penyelenggaran program PPOT dilaksanakan mulai tahun 2004. Sebelumnya dilakukan program orang tua dengan berbagai macam cara atau metode tetapi tidak berjalan sesuai yang diharapkan. Padahal kegiatan ini gratis tanpa dipungut biaya, orang tua dijamu dan disedikan makan siang namun tidak berjalan sehingga akhirnya diwajibkan yang pada awalnya hanya himbauan saja. Menurut Wismiarti, diluar negeri kegiatan - kegiatan sekolah yang memberikan informasi kepada orang tua seperti ini sangat dihormati oleh orang tua. Walaupun dilaksanakan pada malam hari jam tujuh malam sampai jam 10 malam, orang tua menghadiri dan seluruh tempat duduknya terisi. Hal ini terjadi karena mereka memahami betul hal ini dilakukan untuk anak mereka. Banyak orang tua saat ini yang mengatakan bahwa sibuk atau tidak memiliki waktu untuk anaknya sehingga mereka menitipkan anaknya kepada sekolah, jika orang tua sibuk maka siapa yang memiliki waktu untuk anaknya. Menurut Wismiarti, saat ini sekolah membantu orang tua memberikan program pendidikan kepada anaknya sampai pukul 16.00 dan meminta orang tua untuk sudah berada dirumah siap menyambut anak dan melanjutkan program pendidikan anak di rumah sampai anaknya tidur. Melalui PPOT ini sekolah berusaha menyadarkan peran dan tanggungjawab pendidikan anak, tugas mendidik anak merupakan tugas orang tua bukan tugas siapa - siapa. Setelah anaknya bersekolah di Al Falah, ada seorang dokter yang resign dari pekerjaanya dan memilih praktek dijam saat anaknya berada disekolah serta sudah berada di rumah saat anaknya pulang. Selain itu ada juga seorang ibu pejabat tinggi di BUMN yang melakukan hal yang sama, yaitu keluar dari pekerjaannya agar dapat maksimal melaksanakan program pendidikan bagi anaknya dirumah. Jadi PPOT ini banyak menyadarkan orang tua akan tugasnya dalam memberikan program pendidikan kepada anak - anaknya.

PPOT dilakukan dengan pemberian pemahaman materi dengan diskusi, melihat proses pembelajaran siswa dengan observasi, menuliskan hal - hal yang ditemukan dan menjelaskan hasil observasi dalam presentasi, kemudian orang tua juga merasakan sebagai siswa atau guru dengan melaksanakan simulasi praktek. Hal ini dilakukan dalam rangka membangun otak, karena otak belajar 
dengan melakukan banyak hal seperti yang anak - anak lakukan di kelas dengan mendatangi 7 sentra untuk membangun hak yang sama. Menurut Wismiarti, PPOT ini juga membangun orang tua untuk dapat menjadi guru yang baik untuk anak - anaknya, diantaranya membangun dan meningkatkan kemampuan membaca dan menulis, karena sulit menjadi guru jika kemampuan membaca dan menulis rendah. PPOT juga membangun kesamaan antara kata dan perbuatan, working memory, seperti yang diungkapkan beliau, "Hal ini membangun sama kata dengan perbuatan, working memory, mengingat apa yang dibicarakan (diskusikan) tadi, cari di anak-anak, kemudian kita rumuskan, kemudian menjelaskan. Kemudian balik, praktek melakukan apa yang dituliskan". Program PPOT yang disiapkan oleh Sekolah Al Falah dilakukan secara berurutan .

Tabel 1. Tujuh Program Guru dan Orang Tua (PPOT) Sekolah Al Falah.

(Kasali, 2019)

\begin{tabular}{|c|c|c|c|}
\hline No & Tema PPOT & Keterangan & Waktu \\
\hline 1 & $\begin{array}{l}\text { Program } 18 \\
\text { Sikap }\end{array}$ & $\begin{array}{l}\text { Membahas sikap dasar yang jika dimiliki dapat } \\
\text { membuat orang tua dan guru mampu } \\
\text { berkomunikasi dan menjalin hubungan baik } \\
\text { dengan anak }\end{array}$ & 8 hari \\
\hline 2 & $\begin{array}{l}\text { Progam } \\
\text { Membangun } \\
\text { Kecerdasan } \\
\text { Anak }\end{array}$ & $\begin{array}{l}\text { Membahas kriteria kecerdasan anak dan } \\
\text { bagaimana mengaturnya, serta kegiatan-kegiatan } \\
\text { apa saja yang dapat } \\
\text { membangun/memaksimalkan kecerdasan anak }\end{array}$ & 5 hari \\
\hline 3 & $\begin{array}{l}\text { Program } \\
\text { Tahap } \\
\text { Perkembangan } \\
\text { Anak }\end{array}$ & $\begin{array}{l}\text { Membahas tahap-tahap perkembangan anak usia } \\
\text { dini berdasarkan pendapat para ahli pendidikan } \\
\text { masa kini. Sehingga orang tua dan guru mampu } \\
\text { mendeteksi sejak awal jika terjadi keterlambatan } \\
\text { perkembangan }\end{array}$ & 5 hari \\
\hline 4 & $\begin{array}{l}\text { Program } \\
\text { Kegiatan } \\
\text { Main }\end{array}$ & $\begin{array}{l}\text { Membahas tentang main sensorimotor, main } \\
\text { peran, main pembangunan, serta main dengan } \\
\text { aturan dan kegiatan/aktivitas main berkualitas } \\
\text { yang dapat merangsang perkembangan } \\
\text { kecerdasan seorang anak }\end{array}$ & 5 hari \\
\hline 5 & $\begin{array}{l}\text { Program } \\
\text { Pendidikan } \\
\text { tentang Tema } \\
\text { dengan } \\
\text { Lesson Plan } \\
\text { Individual }\end{array}$ & $\begin{array}{l}\text { Membahas manfaat tema dan theme storming, } \\
\text { perencanaan pembelajaran serta praktik } \\
\text { pelaksanaan untuk satu anak (individual) }\end{array}$ & 6 hari \\
\hline
\end{tabular}




\begin{tabular}{cllc}
\hline 6 & $\begin{array}{l}\text { Program } \\
\text { Sentra, Lesson } \\
\text { Plan Sentra } \\
\text { dan Praktik }\end{array}$ & $\begin{array}{l}\text { Membahas kegiatan main, materi, media, untuk } \\
\text { membangun perkembangan anal di setiap sentra } \\
\text { dan praktik pelaksanaan Leson Plan }\end{array}$ & 6 hari \\
\hline 7 & $\begin{array}{l}\text { Program } \\
\text { Magang }\end{array}$ & $\begin{array}{l}\text { Membahas manfaat tema dan theme storming, } \\
\text { perencanaan pembelajaran, serta praktik }\end{array}$ & 6 hari \\
& $\begin{array}{l}\text { Lesoon Plan } \\
\text { Kelompok }\end{array}$ & $\begin{array}{l}\text { pelaksanaan pembelajaran untuk kelompok atau } \\
\text { kelas }\end{array}$ & \\
\hline
\end{tabular}

Berdasarkan tabel diatas PPOT dilakukan secara berurutan dari PPOT 1 sampai dengan PPOT 7. Tema PPOT 1 adalah membahas sikap dasar, hal ini dilakukan karena sikap merupakan kunci dalam belajar. Jika sikap belajarnya salah maka tidak akan tercapai tujuan belajar yang diinginkan. Ada 18 sikap yang dibahas dan dibangun di PPOT 1, diantaranya hormat, jujur, mutu, bersih, kasih sayang, sabar, syukur, ikhlas, disiplin, tanggungjawab, khusyu, rajin, berfikir positif, ramah, rendah hati, qonaah, taqwa dan istiqomah. PPOT 2 tentang knowledge yang harus diketahui orang tua, tentang tubuh manusia karena yang akan dididik anak manusia sehingga harus mengerti tentang anak, mulai dari fisik, otak, kecerdasan, sikap, dan skillnya. Ilmu pengetahuan yang di dapatkan di PPOT diharapkan dapat membangun sikap bukan hanya sebatas pengetahuan saja dan tidak bermanfaat untuk hidupnya, termasuk ibadah - ibadah yang Alloh perintahkan kepada kita. Hal ini seperti yang diungkapkan Wismiarti,
"Semua ibadah yang Allah berikan ke kita itu, supaya akhlak kita baik. Kita harusnya ambil itu untuk pendidikan".(Wismiarti, personal communication, 2020)

Sekolah Al Falah merasakan manfaat dalam proses pendidikan anak jika orang tua bekerja mendidik anaknya setelah mengikuti PPOT. Hal ini terlihat dengan tahap perkembangan anaknya maju cepat sehingga membantu kerja guru di sekolah. Dukungan orang tua sangat dibutuhkan dalam melaksanakan programnya, misalnya di Sekolah Al Falah orang tua dilarang marah - marah kepada anak di rumah. Jika orang tua marah-marah dirumah maka akan terlihat pada anaknya saat disekolah dan ini yang akan menambah berat tugas guru disekolah. Hal ini juga didukung dengan teori otak, kita bangun setiap pagi beda bangun dari hari yang kemarin otaknya. Berbeda ke arah mana, tergantung apa yang masuk ke otak kita satu hari agar besok pagi kita berubah. 
Hambatan - hambatan yang dirasakan sekolah dalam melaksanakan program PPOT ini adalah tidak banyak orang tua yang mengerti bahwa mereka harus mendidik anak di luar jam sekolah padahal anak - anak harus tetap dididik. Hal ini dikarenakan otak anak terus belajar selama 24 jam. Bahkan menurut Wismiarti, malam pun waktu tidur ada proses untuk memindahkan, menyusun, merapihkan semua pengalaman satu hari dan dimasukkan ke memori jangka panjang di sistem limbik. Jadi pulang sekolah, idealnya orang tua sudah menyambut anak, siap melanjutkan pendidikan anak sampai anak tidur. Saat anak tidur, dihantarkan, saat anak tidur dangkal, orang tua doakan, dibacakan $\mathrm{Al}$ Fatihah dan bisa juga dibacakan Asmaul Husna. Hal ini dilakukan agar yang ditransfer ke memori jangka panjang hanya yang diridhoi Allah saja. Selain itu jika ada pengalaman satu hari yang tidak bermutu orang tua dapat merapikan pengalaman hidup satu harinya, seperti yang diungkapkan oleh Wismiarti "jika ada yang salah dikeluarkan diganti dengan hal-hal yang baik, melaui story reading, dibacakan ayat, cerita nabi, sehingga kan rapi otak anak, yang salah sudah dibuang".
Sekolah Al - Falah dalam mengevaluasi program ini dengan melihat tahap perkembangan anak. Hal ini seperti yang diungkapkan Wismiarti, "Cara sekolah melihat ini sederhana, dengan melihat tahap perkembangan anak. Kalau tidak maju, kita cek, ini salah siapa guru atau orang tua". Sekolah dapat melihat lagi lesson plan guru dan melihat hasil pekerjaan anak di sekolah. Setiap hari gurunya berkumpul setelah anak pulang sekolah untuk membahas kegiatan 1 hari. Setiap hari Sabtu guru berkumpul kembali untuk bahas kegiatan satu minggu dan melihat kembali lesson plan yang sudah disiapkan dan dapat melakuan perbaikan lesson plan jika dibutuhkan minggu depan dengan melihat kenyataan minggu sebelumnya.

Awalnya progam ini diberikan untuk guru dan orang tua Sekolah Al Falah saja. Namun dalam perjalanannya banyak guru maupun orang tua luar Sekolah Al Falah, bahkan dosen ikut program ini. Saat ini peserta PPOT berasal dari seluruh wilayah Indonesia baik dari Jawa maupun luar Jawa.(Kasali, 2019)

\section{KESIMPULAN}

Sekolah Al Falah melaksanakan program pembinaan orang tua dalam bentuk pelatihan yang dinamakan 
Program Pelatihan Guru dan Orang Tua (PPOT). PPOT ini telah dilaksanakan sejak tahun 2004 yang wajib diikuti oleh orang tua. Program parenting seperti ini sebenarnya sudah dilaksanakan sejak tahun sekolah berdiri tahun 1996, pada awalnya program ini bersifat himbauan namun tidak mendapatkan hasil yang harapkan, padahal sekolah telah melakukan berbagai macam cara untuk menghadirkan orang tua ke sekolah. Sekolah Al - Falah mewajibkan orang tua untuk terlibat dalam pendidikan anaknya tidak hanya menyerahkan sepenuhnya pendidikan kepada sekolah. Orang tua harus mampu menjadi guru yang baik untuk anak - anaknya karena orang tua adalah guru pertama, sekolah membantu orang tua sebagai guru kedua. Komitmen untuk mengikuti kegiatan ini dilakukan diawal sebelum orang tua bergabung disekolah sehingga partisipasi orang tua menjadi maksimal karena menjadi syarat wajib. PPOT di Al Falah dilakukan dengan berbagai macam metode sehingga mampu menyadarkan orang tua sebagai pendidik bagi anak-anaknya dan juga membuat orang tua memiliki skill dalam mendidik anak - anaknya. Metode yang dilaksanakan adalah dengan pemberian materi, melakukan observasi pembelajaran dan simulasi sebagai murid dan guru. sehingga memberikan efek yang mendalam kepada orang tua. Sekolah sekolah, khususnya sekolah Islam dapat membuat program pembinaan orang tua sebagai bagian program kerja sekolah dan merupakan komitmen bersama diawal pendaftaran sehingga menjadi perhatian bersama. Mengingat sebagus apapun program pendidikan yang dilaksanakan disekolah tidak akan berjalan dengan maksimal tanpa dukungan orang tua.

\section{DAFTAR RUJUKAN}

Al-Hamat, A. (2016). Tarbiyah Jihadiyah Imam Bukhari: Studi Analisis Hadist - Hadist Kitab Jihad Wa Syiar Shahih Bukhari. Ummul Qura.

Al-Nahlawi, A. (1996). Pendidikan Islam di Rumah, Sekolah, dan Masyarakat. Gema Insani Press.

Amin, A. (2018). Sinergisitas Pendidikan Keluarga, Sekolah Dan Masyarakat; Analisis Tripusat Pendidikan. AtTa'lim: Media Informasi Pendidikan Islam, 16(1), 106-125. https://doi.org/10.29300/attalim.v16 i1.824

asy-Syantut, K. A. (2005). Daurut Bait Fii Tarbiyatil Athfalil Muslim, diterjemahkan oleh Rosyad Nurdin dan Y. Nurbayan dengan judul Rumah Pilar Utama Pendidikan Anak. Robbani Press.

Buseri, K. (2014). Dasar, Asas dan Prinsip Pendidikan Islam. IAIN Antasari.

Daradjat, Z. (1994). Pendidikan Islam dalam keluarga dan sekolah. Ruhama.

Fatchurrohman, F. (2012). Kemitraan Pendidikan Membangun relasi sinergis antara sekolah, keluarga, 
dan masyarakat. IAIN Salatiga press. http://e-repository. perpus. iainsalatiga.ac.id/2108/

Hardianto, D. (2014). Program Sekolah Orang Tua Siswa Di Sdit Luqman Al Hakim Internasional Yogyakarta. Dinamika Pendidikan, 21(01), Article 01. https://journal.uny.ac.id/ index.php/dinamikapendidikan/article/view/2852

Hidayat, R. (2016). Ilmu Pendidikan Islam: Menuntun Arah Pendidikan Islam Indonesia. LPPPI.

Ilyasir, F. (2017). Pengembangan Pendidikan Islam Integratif di Indonesia; Kajian Filosofis dan Metode Implementasi. LITERASI (Jurnal Ilmu Pendidikan), 8(1), 3647. https://doi.org/10.21927/literasi. 2017.8(1).36-47

Jainuddin, J. (2019). Peningkatan Hasil Belajar Matematika Melalui Latihan Menyelesaikan Soal Secara Sistematis Pada Siswa Kelas XI. IPA1 SMA Negeri 2 Sungguminasa. Klasikal: Journal Of Education, Language Teaching And Science, 1(3), 44-52.

Kasali, R. (2019). SENTRA Membangun Kecerdasan dan Kemampuan Anak Sejak Usia Dini, Demi Masa Depan yang Cemerlang. Mizan.

Maturidi, M. (2016). Prinsip Perencanaan Manajemen Pendidikan Islam Perspektif Al-Quran. Al-Mabsut: Jurnal Studi Islam dan Sosial, 10(1), 277-296.

Miles, M. B., \& Huberman, M. (1992). Analisis Data Kualitatif. UI Press.

Moleong, Lexy. J. (2000). Metodologi Penelitian Kualitatif. PT Remaja Rosdakarya.

Nata, A. (2017). Ilmu Pendidikan Islam. Prenadamedia.

Raharjo, M. (2019). Jenis dan Metode Penelitian Kualitatif. https:// www.uin-malang.ac.id/r/100601 /jenis-dan-metode-penelitian-

kualitatif.html

Ridwan. (2020). Profil Sekolah Al Falah

[Personal communication].

Sekolah Al Falah: Orang Tua Wajib Terlibat. (2015, November). Direktorat Pembinaan Pendidikan Keluarga Ditjen PAUD Dan DIKMAS, 1, 44.

Sholichah, A. S. (2018). Teori-Teori Pendidikan Dalam Al-Qur'an. Edukasi Islami: Jurnal Pendidikan Islam, 7(01), 23-46. https:// doi.org/10.30868/ei.v7i01.209

Sulasmi, S. (n.d.). Disampaikan pada Pengukuhan Jabatan Guru Besar dalam Bidang Ilmu Manajemen pada Fakultas Ekonomi dan Bisnis Universitas Airlangga di Surabaya pada Hari Sabtu, Tanggal 18 Desember 2010. 34.

Sulasmi, S. (2018). Peran Variabel Perilaku Belajar Inovatif, Intensitas Kerjasama Kelompok, Kebersamaan Visi Dan Rasa Saling Percaya Dalam Membentuk Kualitas Sinergi. Ekuitas (Jurnal Ekonomi dan Keuangan), 13(2), 219-237. https://doi.org/10.24034/j25485024. y2009.v13.i2.295

Syantut, K. A. (2019). Rumahku Madrasah Pertamaku. Maskana Media.

Tafsir, A. (2016). Ilmu Pendidikan Islami. PT. Remaja Rosdakarya.

Wismiarti. (2020). Program Pembinaan Orang Tua Siswa Sekolah Al Falah [Personal communication].

Yusuf, M. (2018). Pengantar Ilmu Pendidikan,: Lembaga Penerbit Kampus IAIN Palopo. 